\title{
MINERALOGIE ŽELEZNÝCH RUD Z ROZVODNÉHO VRCHU U ČABOVÉ VE STŘEDNÍ ČÁSTI ŠTERNBERSKO-HORNOBENEŠOVSKÉHO PRUHU (MORAVSKOSLEZSKÁ JEDNOTKA ČESKÉHO MASIVU)
}

\author{
Mineralogy of the iron ores from the Rozvodný vrch Hill near Čabová in the central part \\ of the Šternberk-Horní Benešov belt (Moravian-Silesian Unit, Bohemian Massif)
}

\author{
Jiří Zimák', Lenka Urbanová2, Lenka Kopecká3 \\ ${ }^{1}$ Katedra geologie PřF UP, tř. 17. listopadu 12, 77146 Olomouc; e-mail: jiri.zimak@upol.cz \\ ${ }^{2}$ Lavičné 25, 56904 Lavičné; e-mail: lenkasabatkova@seznam.cz \\ ${ }^{3}$ URGA, s.r.o., Holická 31A, 77200 Olomouc; e-mail: urga@urga.cz
}

(15-33 Moravský Beroun)

Key words: Šternberk-Horní Benešov belt, iron ore, magnetite, stilpnomelane, chamosite, siderite, iron calcite, chlorite compositional geothermometry

\begin{abstract}
The Čabová deposit of the Lahn-Dill type is located in the historical Beroun iron-ore district in the central part of the Devonian Šternberk-Horní Benešov Belt, consisting of metasedimentary and metavolcanic rocks (metabasites prevail). Iron ores in the district were mined mainly in the 19th century. This article summarizes the results of mineralogical research of iron ores obtained from a heap on the Rozvodny vrch Hill at Čabová. Six types of ores were distinguished: 1/ so-called jaspilite ores (ferruginous jasper with a variable content of hematite and magnetite, usually a very poor iron ore), 2/ jaspilite ores rich in magnetite and/or hematite, 3/ quartz-hematite ores, 4/ quartz-magnetite ores (stilpnomelane is often present), 5/ carbonate ores (siderite is an essential component, also calcite, hematite, magnetite, quartz and stilpnomelane may be present in substantial quantities), and 6/ chlorite ores (composed mainly of chamosite, which is accompanied by varying quantities of calcite, stilpnomelane, ilmenite, white mica, quartz and albite). Up to several centimetres thick veins consisting mainly of calcite and/or quartz penetrate ores. Common part of the veins are chlorite (chamosite) and stilpnomelane, less abundant are white mica, magnetite and hematite, barite is rare. Compositional chlorite geothermometers of Kranidiotis and MacLean (1987) and Zang and Fyfe (1995) yielded temperatures of formation of the ore and vein chlorites that range from 189 to $225^{\circ} \mathrm{C}$ and from 206 to $267^{\circ} \mathrm{C}$, respectively (there is no fundamental difference between the chlorites of the iron ores and the veins).
\end{abstract}

Úvod

Berounský (moravskoberounský) železnorudný revír lze na základě značného objemu těžby v 19. století zařadit mezi historicky nejvýznamnější rudní revíry jesenické oblasti. Součástí tohoto revíru jsou ložiska na k. ú. Čabová, kde v letech 1828-1874 probíhala těžba na více než 20 dolech (Tomšík 1993). Geologické poměry na ložiskách u Čabové hodnotí Kretschmer (1917), v jehož době byly některé $\mathrm{z}$ dolů ještě př́stupné. Kolem r. 1930 byla na Rozvodném vrch u Čabové vyhloubena Vítkovickým těžařstvem jáma (k zamýšlené těžbě však nedošlo), v 50. letech 20 . století zde byl proveden geofyzikální průzkum a na něj navazující geologicko-průzkumné práce - jáma s překopem, šachtice a vrty (Skácel 1966, 1968, 2000). V současnosti je lokalizace většiny starých důlních děl v terénu problematická nebo zcela nemožná; přehlednou mapku s vyznačením důlních měr v berounském revíru zveřejnil Staněk (1997), a to na základě podkladů v nepublikované zprávě $Z$. Pouby z r. 1952.

Železnorudné akumulace lahn-dillského typu u Čabové jsou součástí horninového prostředí šternbersko-hornobenešovského pruhu. Některá rudní tělesa probíhají při kontaktu vulkanické série $s$ nadložními břidlicemi, jiná jsou uvnitř vulkanické série, tvořené zde bazickými vulkanity a tufy, $v$ malé míře jsou prítomny keratofyrové horniny - petrografickými poměry se zabývá např.
Kretschmer (1917), Skácel (1966), Dvořák et al. (1986) a Prrichystal $(1986,1990)$.

Údajů o mineralogických poměrech na železnorudných ložiskách u Čabové je ve starší literatuře jen velmi málo (to je zřejmé i z kompendia Burkarta 1953), několik poznámek lze najít v publikacích Skácela (1966) a Zimáka (1999), podrobnější hodnocení ve dvou diplomových pracích (Šabatková 2009; Kopecká 2012). Tento článek přináší mineralogickou charakteristiku železných rud z Rozvodného vrchu u Čabové.

\section{Vzorky a metody}

Místo odběru vzorkủ rud (N 4949'25" E 17²9'01", odečteno na www.mapy.cz) leží zhruba $350 \mathrm{~m}$ s. od kóty 673,2 m, označované jako Rozvodný vrch, ve starší literatuře jako „Sornickel“ nebo „Sanikel“. Vzorky byly odebrány z montánní haldy v blízkosti hranice důlních měr Sofie (Zophia) a Josef (Joseph) převážně v 80 . letech 20. století, kdy zde bylo možno najít dostatek materiálu z rudního tělesa zastiženého př̀ hloubení jámy (tyto vzorky jsou označeny jako RV-1 až RV-76). V současnosti je rudních fragmentů v uvedeném prostoru výrazně méně díky činnosti sběratelů minerálů po zveřejnění informace (Mátl 1994) o kvalitě zdejšího jaspilitu. Do článku byly začleněny i některé výsledky studia železných rud z blízkosti kóty Železník (vzorek Žel-1) a z důlních měr Josefi 
a Aloisia v prostoru mezi Rozvodným vrchem, Železníkem a obcí Čabová (vzorky Jos-1 až Jos-3 a Aloi-10).

Z vybraných rudních vzorků byly zhotoveny leštěné výbrusy, které byly studovány mikroskopicky v procházejícím i v odraženém světle. Chemické složení sedmi rudních vzorků z k. ú. Čabová bylo stanoveno v Acme Analytical Laboratories Ltd (Vancouver, Kanada) převážně metodou ICP-ES/MS (hmotnost vzorku před homogenizací byla kolem 750 g). Pomocí XRF-analyzátoru DELTA PREMIUM (výrobce Olympus Innov-X Systems, Inc.) byl v laboratořích olomoucké firmy URGA stanoven chemismus 15 vzorků rud. XRF analýza byla provedena v modu GEOCHEM na lehce (tlakem ruky) slisovaném prášku získaném semletím vzorků o hmotnosti cca 600 g. Zjištěné obsahy jednotlivých prvků byly korigovány na základě výsledků analýz 68 rozpráškovaných vzorků hornin a rud (včetně Fe-rud ze šternbersko-hornobenešovského pruhu a vrbenské skupiny), které byly analyzovány za stejných podmínek výše uvedeným XRF-analyzátorem a současně přesnějšími metodami v laboratořích Acme. Vhodnost tohoto postupu při stanovení některých prvků pomocí obdobného „outdoorového“ XRF-analyzátoru prověřili např. Geršl a Knésl (2009). V tabulce 1 jsou uvedeny přepočtené výsledky, a to pouze u prvků vykazujících vysoký koeficient determinace mezi hodnotami zjištěnými v laboratořích Acme a analyzátorem DELTA PREMIUM (a současně s obsahy nad mezí detekce tohoto analyzátoru).

Chemické složení jednotlivých minerálů bylo sledováno pomocí elektronového mikroanalyzátoru Cameca SX100 (PEMM, PřF MU Brno, analytici R. Čopjaková, R. Škoda a P. Gadas, analyzováno převážně v letech 2007-2011). Reprezentativní WDX-analýzy fylosilikátů a karbonátů jsou uvedeny $\mathrm{v}$ tabulkách 4 a 5 - přepočet analýz chloritů byl proveden na 14 atomů kyslíku, muskovitu na 11 atomů kyslíku, karbonátů na $\mathrm{R}^{2+}=1$ (kalcit, siderit) nebo 2 (neurčený karbonát, přepočten jako by šlo $\mathrm{o}$ ankerit), $\mathrm{v}$ př́ípadě stilpnomelanu byl zvolen přepočet na sumu 20 kationtů s vyloučením $\mathrm{K}, \mathrm{Na}, \mathrm{Ba}$ a $\mathrm{Ca}$ (postup Mückeho et al. 2013). WDX analýzy fylosilikátů a karbonátů byly provedeny za těchto podmínek: napětí $15 \mathrm{kV}$, proud $10 \mathrm{nA}$, průměr svazku 4 nebo $5 \mu \mathrm{m}$ (fylosilikáty), 7 nebo
$5 \mu \mathrm{m}$ (karbonáty). Výsledky WDX analýz dalších minerálů jsou pouze stručně komentovány v textu.

\section{Mineralogická charakteristika \\ - hlavní typy železných rud}

V haldovém materiálu na Rozvodném vrchu lze na základě nerostného složení rozlišit šest typů rud: jaspilitové rudy (dále označovány jako rudy typu A), magnetit-hematitové jaspilitové rudy (typ B), křemen-hematitové rudy (typ C), křemen-magnetitové rudy (typ D), karbonátové rudy (typ E) a chloritové rudy (typ F). Rudy typů $\mathrm{A}, \mathrm{B}$ a $\mathrm{C}$ na lokalitě převažují.

Jaspililitové rudy (typ A) mají cihlově červenou barvu, při vyšším obsahu magnetitu a zrnitého hematitu (tedy při přechodu do typu B) mohou být až červenočerné, často jsou (v brekciovitých typech) prostoupeny žilkami šedobílého křemene. Jaspilitová hmota má charakter velmi jemnozrnného agregátu složeného $\mathrm{z}$ xenomorfních zrn křemene (zpravidla do $0,02 \mathrm{~mm}$ ) s velmi drobnými šupinkami hematitu. Vždy jsou př́tomny automorfní až hypautomorfní porfyroblasty magnetitu o velikost zpravidla do 0,2 $\mathrm{mm}$. Místy jsou v rudě magnetitová zrna nahloučená do elipsoidálních nebo kulovitých forem o průměru obvykle do $2-3 \mathrm{~mm}$, na jejichž povrchu jsou individua magnetitu téměr dokonale omezena krystalovými plochami, ve vnitřní části je stupeň automorfie zrn výrazně nižší. Běžně jsou v rudě přítomny drobné jemnozrnné nebo šupinkovité agregáty hematitu, často jde o paprsčité agregáty složené jen z několika hematitových šupinek. Množství magnetitu a hematitu je velmi proměnlivé, při vyšším obsahu magnetitu nebo hematitu přechází do typu $\mathrm{B}$.

Magnetit-hematitové jaspilitové rudy (typ B) jsou obvykle červenočerné, mají šmouhovitou nebo šmouhovitě páskovanou texturu. Kromě partií, jejichž povaha $\mathrm{v}$ podstatě odpovídá typu $\mathrm{A}$, jsou v rudě př́tomny šmouhy až neprůběžné pásky tvořené zrnitým hematitem nebo složené z hypautomorfních až automorfních individuí magnetitu o velikosti do $0,3 \mathrm{~mm}$ (výjimečně až $0,5 \mathrm{~mm}$ ). Kvantitativní zastoupení hematitu a magnetitu je velmi proměnlivé, většinou převažuje hematit nad magnetitem. Ruda někdy obsahuje karbonáty - vtroušeniny kalcitu

Tab. 1: Chemismus železných rud (hm. \%) stanovený pomocí XRF analyzátoru DELTA PREMIUM.

Tab. 1: Chemistry of iron ores (wt. \%) determined by the XRF analyser DELTA PREMIUM.

\begin{tabular}{|l|c|c|c|c|c|c|c|c|c|c|c|c|c|c|c|c|c|}
\hline $\begin{array}{l}\text { typ } \\
\text { rudy }\end{array}$ & A & A + F & B & B & B & B & C & C/D & D & E & E & E & E & E & F & F & F \\
\hline vzorek & Jos-3 & RV-33 & RV-27 & RV-34 & RV-43 & Žel-1 & Aloi-10 & RV-68 & RV-62 & RV-1 & RV-10 & RV-22 & RV-67 & RV-76 & RV-13 & Jos-1 & Jos-2 \\
\hline $\mathrm{SiO}_{2}$ & 72,2 & 23,3 & 36,8 & 51,0 & 55,1 & 51,3 & 53,3 & 28,4 & 47,5 & 45,0 & 64,4 & 33,5 & 36,3 & 55,6 & 22,2 & 15,5 & 17,4 \\
\hline $\mathrm{TiO}_{2}$ & $<0,1$ & 1,9 & $<0,1$ & $<0,1$ & $<0,1$ & $<0,1$ & $<0,1$ & $<0,1$ & 0,2 & $<0,1$ & $<0,1$ & $<0,1$ & 0,1 & $<0,1$ & 2,2 & 6,0 & 3,8 \\
\hline $\mathrm{Al}_{2} \mathrm{O}_{3}$ & 0,4 & 6,5 & 1,1 & 1,1 & 1,2 & 1,4 & 1,0 & 1,9 & 2,2 & 0,4 & 1,1 & 2,6 & 2,8 & 0,7 & 15,3 & 11,1 & 13,7 \\
\hline $\mathrm{FeO}$ & 20,5 & 29,0 & 29,5 & 40,1 & 44,3 & 42,8 & 42,6 & 51,6 & 37,4 & 32,0 & 28,4 & 53,9 & 33,6 & 35,6 & 33,9 & 53,8 & 49,4 \\
\hline $\mathrm{CaO}$ & 0,6 & 10,9 & 10,7 & 4,1 & 0,5 & 0,6 & 0,6 & 7,3 & 3,3 & 8,6 & 2,1 & 4,2 & 7,7 & 0,7 & 1,3 & 3,2 & 1,3 \\
\hline $\mathrm{MnO}$ & $<0,01$ & 0,19 & 0,24 & 0,01 & $<0,01$ & $<0,01$ & $<0,01$ & 0,10 & 0,01 & 0,08 & $<0,01$ & 0,08 & 0,04 & $<0,01$ & 0,03 & 0,10 & 0,03 \\
\hline $\mathrm{K}_{2} \mathrm{O}$ & $<0,10$ & $<0,10$ & 0,19 & $<0,10$ & $<0,10$ & $<0,10$ & $<0,10$ & 0,23 & 0,31 & $<0,10$ & $<0,10$ & $<0,10$ & 0,29 & $<0,10$ & 0,56 & 0,24 & $<0,10$ \\
\hline $\mathrm{P}_{2} \mathrm{O}_{5}$ & 0,10 & 0,78 & 0,24 & 0,12 & 0,11 & 0,10 & 0,13 & 0,23 & 0,11 & 0,11 & 0,10 & 0,11 & 0,10 & 0,11 & 0,41 & 3,87 & 0,73 \\
\hline $\mathrm{S}$ & $<0,01$ & $<0,01$ & 0,04 & $<0,01$ & $<0,01$ & $<0,01$ & 0,01 & $<0,01$ & $<0,01$ & 0,04 & 0,02 & 0,03 & 0,02 & $<0,01$ & 0,12 & $<0,01$ & $<0,01$ \\
\hline $\mathrm{As}$ & $<0,003$ & $<0,003$ & $<0,003$ & $<0,003$ & $<0,003$ & $<0,003$ & $<0,003$ & $<0,003$ & $<0,003$ & $<0,003$ & $<0,003$ & $<0,003$ & $<0,003$ & $<0,003$ & 0,005 & $<0,003$ & $<0,003$ \\
\hline $\mathrm{Zn}$ & $<0,003$ & 0,011 & $<0,003$ & $<0,003$ & $<0,003$ & $<0,003$ & $<0,003$ & $<0,003$ & $<0,003$ & $<0,003$ & $<0,003$ & 0,003 & 0,003 & $<0,003$ & 0,028 & 0,011 & 0,037 \\
\hline
\end{tabular}


nebo i jeho relativně hrubozrnné agregáty tvořící šmouhy, méně obvyklý je jemnozrnný Fe-karbonát (podobné povahy jako v rudách typu $\mathrm{E}$ ).

Křemen-hematitové rudy (typ C) mají šedočernou barvu s namodralým odstínem. Jejich textura je někdy masivní, jindy šmouhovitá, poměrně často brekciovitá. Na složení se často podílí jen oba minerály uvedené v názvu rudního typu. Hematit

Tab. 2: Chemické složení železných rud stanovené v Acme Analytitical Laboratories Ltd.

Tab. 2: Whole-rock composition of iron ores determined in the Acme Analytitical Laboratories Ltd.

\begin{tabular}{|c|c|c|c|c|c|c|c|}
\hline typ rudy & A & B & B & $\mathrm{C}$ & $\mathrm{D}$ & $\mathrm{E}$ & $\mathrm{F}$ \\
\hline vzorek & Jos-3 & RV-43 & Žel-1 & Aloi-10 & RV-62 & RV-22 & Jos-2 \\
\hline $\mathrm{SiO}_{2}(\mathrm{hm} . \%)$ & 80,16 & 49,73 & 53,95 & 52,73 & 52,14 & 31,05 & 13,88 \\
\hline $\mathrm{Al}_{2} \mathrm{O}_{3}(\mathrm{hm} . \%)$ & 0,28 & 0,13 & 0,37 & 0,11 & 0,71 & 0,54 & 10,74 \\
\hline $\mathrm{Fe}_{2} \mathrm{O}_{3}$ (hm. \%) & 18,29 & 49,87 & 43,58 & 46,71 & 42,76 & 55,14 & 62,25 \\
\hline $\mathrm{MgO}$ (hm. \%) & 0,11 & $<0,01$ & 0,01 & $<0,01$ & 0,18 & 0,39 & 2,58 \\
\hline $\mathrm{CaO}$ (hm. \%) & 0,08 & 0,15 & 0,24 & 0,1 & 2,27 & 1,47 & 1,28 \\
\hline $\mathrm{Na}_{2} \mathrm{O}$ (hm. \%) & $<0,01$ & 0,01 & 0,01 & $<0,01$ & 0,01 & $<0,01$ & $<0,01$ \\
\hline $\mathrm{K}_{2} \mathrm{O}(\mathrm{hm} . \%)$ & 0,01 & $<0,04$ & 0,08 & $<0,01$ & 0,15 & 0,12 & 0,02 \\
\hline $\mathrm{TiO}_{2}$ (hm. \%) & 0,05 & $<0,01$ & 0,02 & $<0,01$ & 0,11 & 0,03 & 3,31 \\
\hline $\mathrm{P}_{2} \mathrm{O}_{5}(\mathrm{hm} . \%)$ & 0,098 & 0,1 & 0,201 & 0,132 & 0,16 & 0,06 & 1,025 \\
\hline $\mathrm{MnO}(\mathrm{hm} . \%)$ & 0,1 & 0,01 & 0,03 & $<0,01$ & 0,04 & 0,08 & 0,07 \\
\hline $\mathrm{Cr}_{2} \mathrm{O}_{3}$ (hm. \%) & $<0,002$ & $<0,001$ & $<0,002$ & $<0,002$ & 0,002 & 0,001 & 0,005 \\
\hline LOI (hm. \%) & 0,80 & $-0,10$ & 1,50 & 0,20 & 1,50 & 11,00 & 4,80 \\
\hline TOT/C (hm. \%) & 0,03 & 0,01 & 0,02 & 0,02 & 0,48 & 3,38 & $<0,02$ \\
\hline TOT/S (hm. \%) & $<0,02$ & $<0,01$ & $<0,02$ & 0,02 & $<0,01$ & 0,02 & $<0,02$ \\
\hline suma (hm. \%) & 100,01 & 99,92 & 99,99 & 100 & 100,03 & 99,89 & 99,95 \\
\hline $\mathrm{Ba}(\mathrm{ppm})$ & 108 & 5,6 & 15 & 7 & 59 & 172,6 & 128 \\
\hline $\mathrm{Be}(\mathrm{ppm})$ & $<1,0$ & $<1,0$ & $<1,0$ & 2,0 & $<1,0$ & $<1,0$ & 1,0 \\
\hline Co (ppm) & 4,8 & 0,7 & 1,2 & 1,4 & 1,6 & 0,9 & 76,4 \\
\hline Cs (ppm) & 0,1 & 0,1 & 0,2 & $<0,1$ & 2,6 & 1,9 & 1,5 \\
\hline $\mathrm{Ga}(\mathrm{ppm})$ & 1,2 & $<0,5$ & 1,7 & 5,3 & 1,9 & 1,7 & 33 \\
\hline $\mathrm{Hf}(\mathrm{ppm})$ & 0,1 & $<0,1$ & 0,1 & $<0,1$ & 0,3 & $<0,1$ & 6,0 \\
\hline $\mathrm{Nb}$ (ppm) & 1,0 & 0,2 & 0,6 & $<0,1$ & 2,9 & 0,5 & 35,1 \\
\hline $\mathrm{Rb}(\mathrm{ppm})$ & 0,4 & 0,5 & 1,3 & 0,2 & 2,9 & 1,9 & 1,0 \\
\hline Sn (ppm) & $<1,0$ & 1 & $<1,0$ & $<1,0$ & $<1,0$ & $<1,0$ & $<1,0$ \\
\hline $\mathrm{Sr}(\mathrm{ppm})$ & 4,8 & 6,2 & 4,8 & 8,5 & 61,3 & 30,7 & 19,7 \\
\hline $\mathrm{Ta}(\mathrm{ppm})$ & $<0,1$ & $<0,1$ & $<0,1$ & $<0,1$ & 0,1 & $<0,1$ & 2,5 \\
\hline Th (ppm) & 0,3 & 0,2 & $<0,2$ & $<0,2$ & 0,2 & 0,3 & 1,6 \\
\hline $\mathrm{U}(\mathrm{ppm})$ & 0,2 & 0,4 & 1,1 & 0,3 & 0,3 & 0,4 & 3,4 \\
\hline $\mathrm{V}(\mathrm{ppm})$ & 40,0 & 14,0 & 41,0 & 46,0 & 44,0 & 21,0 & 145,0 \\
\hline $\mathrm{W}$ (ppm) & 1,3 & 1,0 & 12,9 & 3,3 & 2,2 & 0,8 & 2,7 \\
\hline $\mathrm{Zr}(\mathrm{ppm})$ & 3,9 & 1,7 & 4,5 & 1,6 & 9 & 7,3 & 264,8 \\
\hline $\mathrm{Y}(\mathrm{ppm})$ & 2,4 & 1,6 & 2,3 & 1,2 & 4,5 & 2,5 & 30,1 \\
\hline Mo (ppm) & 2,4 & 7,8 & 1,6 & 2,9 & 2,5 & 3,6 & 1 \\
\hline $\mathrm{Cu}(\mathrm{ppm})$ & 4,7 & 3,3 & 4,1 & 4,7 & 2,4 & 7,3 & 1,3 \\
\hline $\mathrm{Pb}(\mathrm{ppm})$ & 1,1 & 1,1 & 2,2 & 2,1 & 3,6 & 1,9 & 1,2 \\
\hline Zn (ppm) & 24,0 & 3,0 & 6,0 & 10,0 & 17,0 & 28,0 & 294,0 \\
\hline $\mathrm{Ni}(\mathrm{ppm})$ & 13,5 & 4,9 & 11,9 & 6,5 & 6,3 & 4,8 & 161,6 \\
\hline As (ppm) & 1,4 & 3,2 & 2,3 & 5,9 & 3 & 0,9 & $<0,5$ \\
\hline $\mathrm{Cd}(\mathrm{ppm})$ & 0,6 & $<0,1$ & $<0,1$ & $<0,1$ & 0,1 & 0,2 & 0,4 \\
\hline $\mathrm{Sb}(\mathrm{ppm})$ & 0,2 & 0,6 & 1,1 & 0,9 & 0,8 & 0,1 & $<0,1$ \\
\hline $\mathrm{Bi}(\mathrm{ppm})$ & $<0,1$ & $<0,1$ & $<0,1$ & $<0,1$ & $<0,1$ & $<0,1$ & $<0,1$ \\
\hline $\mathrm{Ag}(\mathrm{ppm})$ & $<0,1$ & $<0,1$ & 0,1 & $<0,1$ & $<0,1$ & $<0,1$ & $<0,1$ \\
\hline $\mathrm{Au}(\mathrm{ppb})$ & 69,7 & 17,1 & 543,5 & 19,2 & 23,6 & 15,7 & 30,3 \\
\hline $\mathrm{Hg}(\mathrm{ppm})$ & 0,02 & $<0,01$ & 0,01 & 0,02 & $<0,01$ & $<0,01$ & $<0,01$ \\
\hline $\mathrm{Tl}$ (ppm) & $<0,1$ & $<0,1$ & $<0,1$ & $<0,1$ & $<0,1$ & $<0,1$ & $<0,1$ \\
\hline $\mathrm{Se}(\mathrm{ppm})$ & $<0,5$ & $<0,5$ & $<0,5$ & $<0,5$ & $<0,5$ & 0,5 & $<0,5$ \\
\hline
\end{tabular}

tvoří velké agregáty složené $\mathrm{z}$ anizometrických zrn o velikosti zpravidla do $0,05 \mathrm{~mm}$, jen místy jsou přítomny tabulky nebo i drobné šupinky hematitu (typické jaspilitové partie jsou výjimečné). Křemen je relativně hrubozrnný - větší zrna mají až $0,7 \mathrm{~mm}$, jsou výrazně anizometrická, vykazují undulózní zhášení. S rostoucím obsahem hematitu $\mathrm{v}$ rudě průměrná velikost zrn křemene klesá.

Křmen-magnetitové rudy (typ D) jsou šedočerné, někdy s namodralým odstínem. Dominantním rudním minerálem je magnetit, jehož drobná zrna (o velikosti kolem 0,05 mm) bývají seskupena do až 5-6 mm velkých izometrických agregátů, jejichž vnější omezení je tvořeno krystalovými plochami. Součástí rudy jsou jednotlivá hypautomorfní až automorfní individua magnetitu o velikosti do $1 \mathrm{~mm}$. Křemen je velmi jemnozrnný, a to zejména na styku s magnetitovými agregáty, směrem do centra křemenných agregátů se velikost křemenných zrn zvětšuje až na 0,4 mm (tato zrna vykazují výrazné undulózní zhášení). Častou součástí křemenných agregátů jsou jednotlivé šupinky nebo vějíŕky stilpnomelanu. Hematit je v rudě přítomen jen ojediněle - tvoří drobná zrníčka a šupinky inkludované křemenem.

Karbonátové rudy (typ E) mají tmavě hnědou až červenohnědou barvu, jejich šmouhovitě páskovaná textura je jen někdy pozorovatelná již makroskopicky. Charakteristickou složkou rudy jsou jemnozrnné agregáty Fe-karbonátů (identifikován byl siderit), tvořící šmouhy, neprůběžné pásky nebo i formy zcela nepravidelných tvarů, jejichž součástí jsou šupinky a zrníčka hematitu, drobná zrna křemene a magnetitu (zrna magnetitu bývají seskupena do plochých čoček o velikosti až $5 \mathrm{~mm}$ ), šupinky stilpnomelanu, lokálně vtroušeniny pyritu (až 0,5 mm velká hypautomorfní individua hexaedrického typu). Na stavbě rudy se podílí vždy křemenem bohaté jemnozrnné až drobnozrnné čočky, šmouhy nebo neprůběžné pásky. Ve variabilním množství je v rudě přítomen kalcit - je-li podstatnou složkou, pak obvykle tvoří drobnozrnné pásky. Partie bohaté křemenem nebo kalcitem vždy obsahují hematit, magnetit a stilpnomelan (je-li hojný stilpnomelan, nebývá v těchto partiích vysoký podíl hematitu a naopak).

Chloritové rudy (typ F) mají černozelenou barvu. Jejich dominantní složkou je jemně šupinkovitý chlorit, ve variabilním množství je př́ítomen kalcit, jehož zrna mohou vytvářet šmouhovité pásky. $\mathrm{V}$ některých vzorcích je chlorit provázen stilpnomelanem (často $\mathrm{v}$ partiích s kalcitem). V podobě převážně xenomorfních zrn je přítomen magnetit, někdy ruda obsahuje tabulky ilmenitu, šupinky nebo tabulky muskovitu, zrna křemene a albitu. Běžnou akcesorií je minerál skupiny $\mathrm{TiO}_{2}$ a monazit, tvořící místy hojná xenomorfní zrna o velikosti až $0,03 \mathrm{~mm}$, zjištěn byl i apatit. 
Tab. 3: Obsahy vzácných zemin (v ppm) v železných rudách stanovené v Acme Analytitical Laboratories Ltd.

Tab. 3: REE contents (in ppm) in iron ores determined in the Acme Analytitical Laboratories Ltd.

\begin{tabular}{|l|c|c|c|c|c|c|c|}
\hline typ rudy & A & B & B & C & D & E & F \\
\hline vzorek & Jos-3 & RV-43 & Žel-1 & Aloi-10 & RV-62 & RV-22 & Jos-2 \\
\hline La & 1,6 & 1,4 & 1,7 & 1,4 & 3,6 & 2,7 & 14,0 \\
\hline Ce & 3,1 & 1,9 & 4,2 & 1,4 & 6,3 & 6,3 & 30,3 \\
\hline Pr & 0,36 & 0,32 & 0,54 & 0,24 & 0,95 & 0,64 & 4,70 \\
\hline Nd & 1,7 & 1,3 & 2,2 & 1,1 & 3,9 & 2,7 & 20,2 \\
\hline Sm & 0,43 & 0,30 & 0,48 & 0,20 & 0,60 & 0,60 & 5,21 \\
\hline Eu & 0,17 & 0,08 & 0,15 & 0,06 & 0,26 & 0,21 & 1,52 \\
\hline Gd & 0,57 & $<0,50$ & 0,52 & 0,24 & 0,91 & 0,59 & 6,00 \\
\hline Tb & 0,11 & 0,05 & 0,10 & 0,05 & 0,14 & 0,08 & 0,76 \\
\hline Dy & 0,49 & 0,26 & 0,49 & 0,21 & 0,59 & 0,53 & 5,04 \\
\hline Ho & 0,09 & 0,04 & 0,12 & 0,05 & 0,12 & 0,09 & 0,99 \\
\hline Er & 0,26 & 0,16 & 0,28 & 0,13 & 0,39 & 0,29 & 3,03 \\
\hline Tm & 0,04 & 0,02 & 0,05 & 0,03 & 0,04 & 0,04 & 0,39 \\
\hline Yb & 0,17 & 0,09 & 0,23 & 0,11 & 0,22 & 0,19 & 2,60 \\
\hline Lu & 0,04 & 0,03 & 0,05 & 0,03 & 0,05 & 0,04 & 0,39 \\
\hline suma & 9,13 & 5,95 & 11,11 & 5,25 & 18,07 & 15,00 & 95,13 \\
\hline LREE & 7,19 & 5,22 & 9,12 & 4,34 & 15,35 & 12,94 & 74,41 \\
\hline HREE & 1,94 & 0,73 & 1,99 & 0,91 & 2,72 & 2,06 & 20,72 \\
\hline HREE/LREE & 0,27 & 0,14 & 0,22 & 0,21 & 0,18 & 0,16 & 0,28 \\
\hline
\end{tabular}

Rudami pronikají vlasové žilky až několik cm mocné žilky tvořené kalcitem nebo křemenem v různém kvantitativním poměru. Podstatnou složkou některých žilek jsou fylosilikáty, zastoupené hlavně stilpnomelanem (až $3 \mathrm{~mm}$ velké hnědavě černé lupínky, prrítomné zejména při okraji kalcitových žilek) a chlorit (tmavě zelené až černozelené jemně šupinkovité agregáty); ojedinělou součástí žilek je muskovit (drobné tabulky a šupinky při okraji žilek). Součástí žilek může být zrnitý magnetit a zejména hrubě lupenitý hematit (hojný na křemenných žilkách). Na kal- citové žilce $\mathrm{v}$ rudě typu $\mathrm{F}$ byla zjištěna xenomorfní zrna barytu o velikosti do 0,003 mm (ověřeno EDX).

Rudní vzorky z haldy na Rozvodném vrchu jsou jen nepatrně postiženy supergenními procesy, které se projevují slabou limonitizací Fe-karbonátů a někdy i chloritu a stilpnomelanu. Železné rudy z blízkosti kóty Železník a z důlních měr Josefi a Aloisia jsou zvětráváním ovlivněny mnohem výrazněji (karbonáty jsou často vylouženy, dutiny po nich bývají vyplněny limonitem). Stupeň supergenního postižení se projevuje i rozsahem martitizace magnetitu $\mathrm{v}$ rudách $\mathrm{z}$ Rozvodném vrchu je rozsah této přeměny jen nepatrný, v rudách od Železníku a z důlních měr Josefi a Aloisia jsou přítomny i dokonalé pseudomorfózy hematitu po magnetitu.

\section{Chemismus rud a vybraných minerálů}

Chemismus rud je zřejmý z tabulek 1 až 3, do nichž byly začleněny údaje o složení vzorků reprezentujících výše rozlišené rudní typy $\mathrm{A}$ až $\mathrm{F}$, do tabulky 1 byl zařazen i vzorek se složením na rozhraní typů C a D (v tabulce C/D) a také vzorek brekciovité rudy s klasty odpovídajícími typům A a F (v tabulce A+F).

Reprezentativní WDX analýzy karbonátů (kalcit, siderit a neurčený karbonát - viz následující kapitola) a fylosilikátů (stilpnomelan, chlorit, muskovit) jsou uvedeny v tabulkách 4 a 5 . V magnetitu bylo vedle dominantního Fe v analyzovaných bodech zjištěno (v hm. \%) až $0,73 \mathrm{TiO}_{2}$, $0,77 \mathrm{SiO}_{2}, 0,17 \mathrm{Al}_{2} \mathrm{O}_{3}, 0,10 \mathrm{Cr}_{2} \mathrm{O}_{3}$ a $0,12 \mathrm{~V}_{2} \mathrm{O}_{3}$. Ilmenit obsahuje (v apfu, na bázi 3 atomy kyslíku) 0,06 Si, 0,04 Al, $0,02 \mathrm{Mg}$ a $0,01 \mathrm{Mn}$. V monazitu zcela nepatrně převažuje Ce nad sumou $\mathrm{La}+\mathrm{Nd}$, počty atomů těchto tř́ prvků (apfu, na bázi 4 atomy kyslíku) jsou následující: 0,42-0,44 Ce, $0,22-0,27$ La a $0,15-0,18 \mathrm{Nd}$.

Tab. 4: Chemismus karbonátů v železných rudách a na hydrotermálních žilkách (hm. \%).

Tab. 4: Chemistry of carbonates in iron ores and hydrothermal veins (wt. \%).

\begin{tabular}{|c|c|c|c|c|c|c|c|c|c|c|c|c|c|c|}
\hline \multirow[b]{3}{*}{ vzorek } & \multicolumn{6}{|c|}{ kalcit } & \multirow{2}{*}{\multicolumn{5}{|c|}{$\begin{array}{l}\text { siderit } \\
\text { ruda }\end{array}$}} & \multirow{2}{*}{\multicolumn{3}{|c|}{$\begin{array}{c}\text { neurčitelný karbonát } \\
\text { ruda }\end{array}$}} \\
\hline & \multicolumn{3}{|c|}{ ruda } & \multicolumn{3}{|c|}{ žilka } & & & & & & & & \\
\hline & RV-22 & RV-22 & RV-62 & RV-10 & RV-62 & RV-68 & RV-22 & RV-22 & RV-22 & RV-76 & RV-76 & RV-1 & RV-1 & RV-1 \\
\hline $\mathrm{CaO}$ & 52,67 & 53,87 & 53,03 & 51,66 & 50,63 & 53,30 & 0,54 & 0,69 & 0,65 & 0,68 & 0,73 & 37,15 & 39,32 & 36,51 \\
\hline $\mathrm{FeO}$ & 3,97 & 3,33 & 3,37 & 3,81 & 2,66 & 3,11 & 59,11 & 58,76 & 58,08 & 60,52 & 59,36 & 21,94 & 19,06 & 22,98 \\
\hline $\mathrm{MgO}$ & 0,11 & 0,25 & 0,19 & 0,06 & 0,21 & 0,28 & 1,71 & 1,13 & 2,39 & 0,69 & 1,01 & 0,03 & 0,02 & 0,04 \\
\hline $\mathrm{MnO}$ & 0,06 & 0,27 & 0,23 & 0,13 & 0,82 & 0,24 & 0,23 & 0,10 & 0,35 & 0,07 & 0,16 & 0,53 & 0,09 & 0,30 \\
\hline SrO & - & 0,01 & 0,09 & 0,10 & 0,10 & 0,28 & - & - & - & - & - & - & - & - \\
\hline $\mathrm{ZnO}$ & - & - & nest. & - & - & nest. & - & - & - & - & 0,03 & - & - & - \\
\hline $\mathrm{BaO}$ & - & - & nest. & 0,01 & 0,02 & nest. & - & - & - & - & - & - & - & - \\
\hline $\mathrm{K}_{2} \mathrm{O}$ & nest. & nest. & - & nest. & nest. & - & nest. & nest. & nest. & - & 0,01 & - & - & - \\
\hline $\mathrm{P}_{2} \mathrm{O}_{5}$ & nest. & nest. & 0,03 & 0,03 & 0,03 & 0,02 & nest. & nest. & nest. & - & 0,04 & - & - & - \\
\hline $\mathrm{SiO}_{2}$ & - & 0,01 & nest. & 0,08 & 0,01 & nest. & 0,04 & 1,20 & 0,07 & 0,02 & 0,32 & 0,21 & 0,11 & 0,15 \\
\hline $\mathrm{Al}_{2} \mathrm{O}_{3}$ & 0,08 & - & - & nest. & nest. & 0,02 & 0,11 & 0,66 & 0,19 & 0,01 & 0,02 & 0,11 & 0,08 & 0,06 \\
\hline $\mathrm{SO}_{3}$ & - & - & - & nest. & nest. & 0,01 & - & 0,03 & 0,02 & 0,01 & - & - & - & - \\
\hline suma & 56,89 & 57,74 & 56,94 & 55,88 & 54,48 & 57,26 & 61,74 & 61,68 & 61,75 & 62,00 & 61,68 & 59,97 & 58,68 & 60,04 \\
\hline \multicolumn{15}{|c|}{ počet kationtů (apfu): } \\
\hline $\mathrm{Ca}^{2+}$ & 0,941 & 0,944 & 0,944 & 0,941 & 0,943 & 0,944 & 0,011 & 0,014 & 0,013 & 0,014 & 0,015 & 1,357 & 1,448 & 1,334 \\
\hline $\mathrm{Fe}^{2+}$ & 0,055 & 0,046 & 0,047 & 0,054 & 0,039 & 0,043 & 0,937 & 0,936 & 0,914 & 0,965 & 0,953 & 0,626 & 0,548 & 0,655 \\
\hline $\mathrm{Mg}^{2+}$ & 0,003 & 0,006 & 0,005 & 0,002 & 0,005 & 0,007 & 0,048 & 0,047 & 0,067 & 0,020 & 0,029 & 0,002 & 0,002 & 0,002 \\
\hline $\mathrm{Mn}^{2+}$ & 0,001 & 0,004 & 0,003 & 0,002 & 0,012 & 0,003 & 0,004 & 0,004 & 0,006 & 0,001 & 0,003 & 0,015 & 0,003 & 0,009 \\
\hline $\mathrm{Sr}^{2+}$ & - & - & 0,001 & 0,001 & 0,001 & 0,003 & - & - & - & - & - & - & - & - \\
\hline
\end{tabular}




\section{Diskuze}

1) V haldovém materiálu na Rozvodném vrchu jsou zastoupeny hlavně „kyselé rudy“ (typy A, B, C a D - rudy typu $\mathrm{B}$ převažují), méně hojné jsou zde „zásadité rudy“ obsahující jako podstatnou složku siderit nebo chamosit (typy E a F). Rudy typu A jsou na železo relativně chudé, jeho obsah je vždy pod $20 \mathrm{hm}$. \% Fe (a nutno poznamenat, že rudnina této povahy by k výrobě železa nebyla využitelná). V rudách všech ostatních typů jsou obsahy Fe v průměru mezi 30 a $35 \mathrm{hm}$. \%, nejvyšší obsahy Fe v jednotlivých rudních vzorcích byly zjištěny u typů $\mathrm{E}$ a F (shodně $42 \mathrm{hm}$. \%). Pro rudy typu F jsou vedle relativně nízkých obsahů $\mathrm{SiO}_{2}$ a vysokých obsahů $\mathrm{Al}_{2} \mathrm{O}_{3}$ charakteristické zvýšené koncentrace titanu, fosforu (tab. 1 a 2) a také prvků skupiny vzácných zemin (tab. 3), vázaných patrně hlavně na monazit - $(\mathrm{Ce})$. To je dáno rozdílnou povahou protolitu: u typů A až E šlo primárně o hydrotermálně-sedimentární silicity s vysokým podílem oxidů a oxihydroxidů Fe s lokálními akumulacemi Fe-karbonátů a s př́měsí pyroklastického materiálu, protolit rud typu $\mathrm{F}$ je patrně produktem hydrotermální alterace bazických vulkanitů, př́p. pyroklastik. Zvýšené obsahy vzácných zemin (hlavně

Tab. 5: Chemismus stilpnomelanu, chloritu a muskovitu v železných rudách a na hydrotermálních žilkách (hm. \%).

Tab. 5: Chemistry of stilpnomelane, chlorite and muscovite in iron ores and hydrothermal veins (wt. \%).

\begin{tabular}{|c|c|c|c|c|c|c|c|c|c|c|c|c|c|c|c|}
\hline \multirow[b]{3}{*}{ vzorek } & \multicolumn{6}{|c|}{ stilpnomelan } & \multicolumn{6}{|c|}{ chlorit } & \multicolumn{3}{|c|}{ muskovit } \\
\hline & \multicolumn{3}{|c|}{ ruda } & \multicolumn{3}{|c|}{ žilka } & \multicolumn{4}{|c|}{ ruda } & \multicolumn{2}{|c|}{ žilka } & ruda & \multicolumn{2}{|c|}{ žilka } \\
\hline & RV-10 & RV-68 & RV-67 & RV-22 & RV-27 & RV-68 & Jos-2 & RV-67 & RV-10 & RV-33 & RV-1 & RV-68 & Jos-1 & RV-68 & RV-68 \\
\hline $\mathrm{SiO}_{2}$ & 43,80 & 43,47 & 43,50 & 43,92 & 43,40 & 44,38 & 24,57 & 24,16 & 24,72 & 24,90 & 22,79 & 23,39 & 45,04 & 47,07 & 46,52 \\
\hline $\mathrm{TiO}_{2}$ & - & 0,02 & - & 0,01 & 0,01 & 0,02 & 0,06 & 0,04 & 0,01 & 0,02 & 0,01 & 0,01 & 0,30 & 0,05 & 0,02 \\
\hline $\mathrm{Al}_{2} \mathrm{O}_{3}$ & 5,82 & 6,43 & 6,48 & 6,14 & 5,77 & 6,22 & 17,04 & 17,59 & 16,36 & 16,64 & 19,65 & 18,38 & 25,50 & 25,90 & 26,60 \\
\hline $\mathrm{Cr}_{2} \mathrm{O}_{3}$ & 0,01 & - & nest. & - & - & 0,01 & 0,02 & - & - & - & - & - & - & 0,03 & 0,03 \\
\hline $\mathrm{V}_{2} \mathrm{O}_{3}$ & nest. & - & nest. & nest. & nest. & - & nest. & nest. & nest. & nest. & nest. & 0,05 & nest. & 0,04 & 0,09 \\
\hline $\mathrm{P}_{2} \mathrm{O}_{5}$ & 0,04 & 0,03 & 0,01 & nest. & nest. & - & - & - & - & nest. & nest. & 0,01 & - & - & - \\
\hline $\mathrm{FeO}$ & 35,52 & 34,98 & 33,73 & 34,59 & 33,43 & 33,81 & 37,69 & 40,72 & 42,38 & 38,92 & 40,20 & 42,62 & 8,20 & 8,97 & 8,30 \\
\hline $\mathrm{MgO}$ & 2,00 & 2,28 & 2,03 & 1,73 & 2,18 & 2,90 & 4,83 & 5,48 & 4,80 & 6,58 & 5,28 & 4,58 & 1,12 & 1,26 & 1,09 \\
\hline $\mathrm{MnO}$ & 0,17 & 0,09 & 0,08 & 0,04 & 0,05 & 0,12 & 0,03 & 0,08 & 0,04 & 0,08 & 0,06 & 0,13 & - & - & 0,04 \\
\hline $\mathrm{NiO}$ & - & - & 0,03 & nest. & nest. & - & 0,12 & 0,01 & 0,05 & nest. & nest. & nest. & 0,03 & nest. & nest. \\
\hline $\mathrm{CaO}$ & 0,25 & 0,32 & 1,32 & 0,48 & 0,47 & 0,35 & 0,14 & 0,04 & 0,07 & 0,04 & - & 0,04 & 0,04 & 0,03 & 0,02 \\
\hline $\mathrm{BaO}$ & 0,66 & 0,79 & 0,62 & nest. & nest. & 0,54 & - & - & 0,02 & nest. & nest. & - & 0,09 & 0,05 & 0,14 \\
\hline $\mathrm{ZnO}$ & 0,02 & 0,05 & - & nest. & nest. & - & 0,09 & 0,02 & - & nest. & nest. & 0,09 & 0,03 & - & - \\
\hline $\mathrm{K}_{2} \mathrm{O}$ & 1,73 & 1,76 & 1,91 & 1,90 & 1,41 & 2,23 & 0,06 & 0,17 & - & 0,01 & 0,02 & 0,03 & 10,47 & 10,53 & 10,79 \\
\hline $\mathrm{Na}_{2} \mathrm{O}$ & 0,04 & - & 0,09 & 0,05 & - & 0,02 & 0,02 & 0,06 & 0,05 & 0,04 & - & 0,01 & 0,16 & 0,04 & 0,13 \\
\hline $\mathrm{Rb}_{2} \mathrm{O}$ & nest. & 0,04 & - & nest. & nest. & 0,02 & & - & - & nest. & nest. & 0,04 & nest. & - & - \\
\hline F & - & - & - & nest. & nest. & - & - & - & - & nest. & nest. & - & 0,15 & 0,08 & 0,12 \\
\hline $\mathrm{Cl}$ & 0,05 & 0,03 & 0,04 & nest. & nest. & 0,01 & - & 0,01 & & nest. & nest. & - & 0,01 & 0,01 & - \\
\hline $\mathrm{O}=\mathrm{F}$ & - & - & - & - & - & - & - & - & - & - & - & - & $-0,06$ & $-0,03$ & $-0,05$ \\
\hline $\mathrm{O}=\mathrm{Cl}$ & $-0,01$ & $-0,01$ & $-0,01$ & - & - & - & - & $-0,00$ & - & - & - & - & $-0,00$ & $-0,00$ & - \\
\hline suma & 90,10 & 90,28 & 89,83 & 88,86 & 86,72 & 90,63 & 84,67 & 88,38 & 88,50 & 87,23 & 88,01 & 89,38 & 91,07 & 94,02 & 93,84 \\
\hline \multicolumn{16}{|c|}{ počet kationtů a aniontů (apfu): } \\
\hline $\mathrm{Si}^{4+}$ & 10,485 & 10,368 & 10,549 & 10,621 & 10,656 & 10,512 & 2,903 & 2,772 & 2,856 & 2,863 & 2,618 & 2,682 & 3,274 & 3,310 & 3,278 \\
\hline $\mathrm{Ti}^{4+}$ & 0,000 & 0,004 & 0,000 & 0,002 & 0,002 & 0,004 & 0,005 & 0,003 & 0,001 & 0,002 & 0,001 & 0,001 & 0,016 & 0,003 & 0,001 \\
\hline $\mathrm{Al}^{3+}$ & 1,642 & 1,807 & 1,852 & 1,750 & 1,670 & 1,736 & 2,373 & 2,379 & 2,228 & 2,255 & 2,660 & 2,484 & 2,184 & 2,147 & 2,209 \\
\hline $\mathrm{Cr}^{3+}$ & 0,002 & - & - & - & - & 0,002 & 0,002 & - & - & - & - & - & - & 0,002 & 0,002 \\
\hline $\mathrm{V}^{3+}$ & - & - & - & - & - & - & - & - & - & - & - & 0,005 & - & 0,002 & 0,005 \\
\hline $\mathrm{P}^{5+}$ & 0,008 & 0,006 & 0,002 & - & - & - & - & - & - & - & - & 0,001 & - & - & - \\
\hline $\mathrm{Fe}^{2+}$ & 7,111 & 6,977 & 6,841 & 6,995 & 6,864 & 6,698 & 3,724 & 3,908 & 4,095 & 3,742 & 3,861 & 4,087 & 0,498 & 0,528 & 0,489 \\
\hline $\mathrm{Mg}^{2+}$ & 0,714 & 0,811 & 0,734 & 0,624 & 0,798 & 1,024 & 0,851 & 0,937 & 0,827 & 1,128 & 0,904 & 0,783 & 0,121 & 0,132 & 0,114 \\
\hline $\mathrm{Mn}^{2+}$ & 0,034 & 0,018 & 0,016 & 0,008 & 0,010 & 0,024 & 0,003 & 0,008 & 0,004 & 0,008 & 0,006 & 0,013 & - & - & 0,002 \\
\hline $\mathrm{Ni}^{2+}$ & - & - & 0,006 & - & - & - & 0,011 & 0,001 & 0,005 & - & - & - & 0,002 & - & - \\
\hline $\mathrm{Ca}^{2+}$ & 0,064 & 0,082 & 0,343 & 0,124 & 0,124 & 0,089 & 0,018 & 0,005 & 0,009 & 0,005 & - & 0,005 & 0,003 & 0,002 & 0,002 \\
\hline $\mathrm{Ba}^{2+}$ & 0,062 & 0,074 & 0,059 & - & - & 0,050 & - & - & 0,001 & - & - & - & 0,003 & 0,001 & 0,004 \\
\hline $\mathrm{Zn}^{2+}$ & 0,004 & 0,009 & - & - & - & - & 0,008 & 0,002 & - & - & - & 0,008 & 0,002 & - & - \\
\hline $\mathrm{K}^{+}$ & 0,528 & 0,536 & 0,591 & 0,586 & 0,442 & 0,674 & 0,009 & 0,025 & - & 0,001 & 0,003 & 0,004 & 0,971 & 0,945 & 0,970 \\
\hline $\mathrm{Na}^{+}$ & 0,019 & - & 0,042 & 0,023 & - & 0,009 & 0,005 & 0,013 & 0,011 & 0,009 & - & 0,002 & 0,023 & 0,005 & 0,018 \\
\hline $\mathrm{Rb}^{+}$ & - & 0,006 & - & - & - & 0,003 & - & - & - & - & - & 0,003 & - & - & - \\
\hline suma & 20,673 & 20,697 & 21,035 & 20,734 & 20,565 & 20,825 & 9,911 & 10,053 & 10,035 & 10,013 & 10,053 & 10,076 & 7,097 & 7,077 & 7,094 \\
\hline $\mathrm{F}^{-}$ & - & - & - & - & - & - & - & - & - & - & - & - & 0,034 & 0,018 & 0,027 \\
\hline $\mathrm{Cl}^{-}$ & 0,020 & 0,012 & 0,016 & - & - & 0,004 & - & 0,002 & - & - & - & - & 0,001 & 0,001 & - \\
\hline $\mathrm{O}^{2-}$ & 31,709 & 31,705 & 32,188 & 31,927 & 31,837 & 31,865 & 14,000 & 13,998 & 14,000 & 14,000 & 14,000 & 14,000 & 10,964 & 10,981 & 10,973 \\
\hline
\end{tabular}


LREE) ve vulkanitech šternbersko-hornobenešovského pruhu jsou zřejmé z práce Přichystala (1990) - citovaným autorem uváděné obsahy REE $\mathrm{v}$ diabasech a keratofyrech $\mathrm{z}$ berounského revíru jsou vyšší než v rudách typu F. Součástí tabulky 3 je hodnota poměru HREE/LREE, která se $\mathrm{v}$ prrípadě rud od Čabové pohybuje v rozpětí 0,14 až 0,28 . Z nepublikovaných dat autora je zřejmé, že pro železné rudy typu Lahn-Dill (kyselé i bazické) v jesenické oblasti je převaha LREE nad HREE typická: v souboru 29 analýz železných rud lahndillského typu z jižní a střední části šternbersko-hornobenešovského pruhu a ze všech úseků vrbenské skupiny jsou hodnoty HREE/LREE v rozpětí 0,09 až 0,42 (HREE $=0,73$ až 41,34 ppm, LREE = 2,16 až 440,69 ppm). Data uváděná Mückem et al. (2013) pro železné rudy z ložiska Horní Benešov lze vzhledem k převaze HREE nad LREE ve všech rudních vzorcích považovat za anomální (nejnižší hodnota HREE/LREE je 1,13). Nutno poznamenat, že na železnorudných akumulacích typu Lahn-Dill v jesenické oblasti byla převaha HREE nad LREE zjištěna autorem této zprávy $\mathrm{v}$ pyritových rudách s magnetitem z Horní Moravice. Rozdíly v chemismu Fe-rud od Čabové a Horního Benešova mohou svědčit o rozdílnosti procesů vzniku obou akumulací. Železné rudy hornobenešovského ložiska se podle Mückeho et al. (2013) geneticky liší od typických železnorudných akumulací lahndillského typu. Podle citovaných autorů lze Fe-rudy hornobenešovského revíru považovat za železem bohatou distální facii spjatou se submarinními hydrotermálními vývěry, jejichž produktem byly polymetalické sulfidické akumulace s barytem. Výše již bylo zmíněno, že pyritové rudy s magnetitem od Horní Moravice se poměrem HREE a LREE podobají železným rudám z Horního Benešova. V př́ipadě Horní Moravice může být genetická interpretace obdobná představě Mückeho et al. (2013), hydrotermálně sedimentární polymetalická sulfidická mineralizace s barytem byla zjištěna jen několik km od hornomoravického ložiska (vrty v blízkosti historického ložiska Nová Ves).

2) Železné rudy s podstatným podílem Fe-karbonátů (typ E) nejsou z ložisek typu Lahn-Dill v sv. části Českého masivu často popisovány, což ale neznamená, že zde nejsou běžným rudním typem. Dokud nebyla k dispozici EDX nebo WDX analýza, byla identifikace Fe-karbonátů v rudách velmi obtížná, v př́ípadě vzorků se silným supergenním postižením nemožná. Ve starších pracích věnovaných berounskému revíru proto rudy tohoto charakteru zmiňovány nejsou, $v$ novějších publikacích je přítomnost Fe-karbonátů uváděna z železnorudných akumulací v jiných úsecích šternbersko-hornobenešovského pruhu (Řídeč, Horní Benešov) a také v severní části vrbenské skupiny. Z povahy materiálu deponovaného na Rozvodném vrchu u Čabové lze usuzovat, že rudy typu E nejsou na ložisku př́liš hojné. Mocnost jejich poloh však musela být alespoň $\mathrm{v}$ některých př́ípadech větší než cca $25 \mathrm{~cm}$. Siderit z Rozvodného vrchu se výraznou dominancí železa $\mathrm{v}$ pozici divalentního kationtu (Fe apfu $=0,91-0,97)$ výrazně liší od sideritů v železných rudách na ložisku Horní Benešov, $\mathrm{v}$ nichž byly zjištěny často značné obsahy $\mathrm{Mn}, \mathrm{Mg}$ a také $\mathrm{Ca}$ (Mücke et al. 2013). Již výše v textu zmiňovaný a v tabulce 4 uvedený „neurčený karbonát“ byl zjištěn ve formě
Tab. 6: Chemismus chloritu ( $\mathrm{Si}$ apfu, F/FM) a na chemismu založená chloritová geotermometrie.

Tab. 6: Chemistry of chlorite (Si apfu, F/FM) and chlorite compositional geothermometry.

\begin{tabular}{|l|c|c|c|}
\hline & ruda typu E & ruda typu F & žilky \\
\hline Si apfu (na bázi 14 at. O) & $2,66-2,86$ & $2,76-2,92$ & $2,62-2,73$ \\
\hline F/FM & $0,81-0,84$ & $0,76-0,83$ & $0,77-0,84$ \\
\hline Cathelineau - Nieva (1985) & $260-302$ & $247-281$ & $286-311$ \\
\hline Cathelineau (1988) & $306-369$ & $287-338$ & $346-383$ \\
\hline Kranidiotis - MacLean (1987) & $200-223$ & $189-211$ & $210-225$ \\
\hline Jowett (1991) & $322-385$ & $301-354$ & $361-698$ \\
\hline Zang - Fyfe (1995) & $215-255$ & $206-236$ & $242-267$ \\
\hline
\end{tabular}

jemnozrnných agregátů pouze v jednom vzorku; v BSE obrazu se tyto agregáty jeví jako homogenní. Výsledky tří bodových analýz tohoto karbonátu (viz tab. 4) jsou si velmi blízké, avšak poměrem $\mathrm{Ca} / \mathrm{Fe}$ neodpovídají ankeritu, a nelze uvažovat ani o Fe-kalcitu (v tomto př́padě je obsah Fe naopak př́liš vysoký). Kalcit s relativně vysokým obsahem železa (Fe apfu $=0,04-0,06)$ je však na Rozvodném vrchu př́tomen, a to jak v Fe-rudách, tak i jako podstatná složka jimi probíhajících žilek. Kalcit s obdobnou koncentrací Fe je uváděn z Horního Benešova, kde však má i zvýšené obsahy Mn a Sr (Mücke et al. 2013).

3) Fylosilikáty jsou v rudách zastoupeny hlavně chloritem a stilpnomelanem. Zatímco chlorit může být i dominantní složkou rudy (typ F), množství stilpnomelanu v rudě jen výjimečně dosahuje 15-20 obj. \%. Již z optických vlastností chloritů v rudách a na žilkách (vždy výrazný pleochroismus od jemně nažloutlé po středně zelenou, anomální šedomodré interferenční barvy) je zřejmé, že jde o Fe-chlority velmi podobného složení, což dokládají i výsledky WDX analýz. Na základě výrazné převahy Fe v oktaedrické pozici lze všechny analyzované chlority označit jako chamosit. Podle starší Melkovy klasifikace založené na Si apfu a hodnotě F/FM odpovídají chlority $\mathrm{v}$ rudě typu E chamositu až thuringitu, v rudě typu F chamositu, na žilkách thuringitu (tab. 6). Rozdíly v chemismu mezi analyzovanými chlority (celkem 20 analýz) jsou však velmi malé a všechny se v Melkově klasifikaci nachází při rozhraní mezi poli chamositu a thuringitu (hranice je na 2,75 Si apfu). Ke zjištění teplot krystalizace chloritů bylo použito pět rozdílných geotermometrů (tab. 6), založených na množství tetraedrického $\mathrm{Al}$ a na poměru $\mathrm{Fe} /(\mathrm{Fe}+\mathrm{Mg})$. Pouze dva $\mathrm{z}$ geotermometrů (Kranidiotis MacLean 1987; Zang - Fyfe 1995) poskytly teploty, které lze považovat za akceptovatelné $\left(189\right.$ až $225^{\circ} \mathrm{C}$ a 206 až $267^{\circ} \mathrm{C}$ ), teploty vypočtené podle tř́ zbývajících jsou nereálně vysoké (tab. 6). Obdobně jako u chloritu, neexistuje žádný zásadnější rozdíl v chemismu a optických vlastnostech stilpnomelanu v rudě a na žilkách. Minerál vykazuje výrazný pleochroismus v barvách charakteristických pro „ferristilpnomelan“ (žlutá x hnědočerná až téměř černá), zcela výjimečně byly ve stilpnomelanu zjištěny drobné „ostrůvky“, jejichž pleochroismus (bledě žlutá x zelená) by odpovídal „ferrostilpnomelanu“. Stilpnomelan z Rozvodného vrchu se chemismem podobá stilpnomelanu z ložiska Rídeč v jižní části šternbersko-hornobenešovského pruhu (Zimák 2015) a také stilpnomelanu ze železných rud na lo- 
žisku Horní Benešov, kde však obsahuje více barya a méně draslíku (Mücke et al. 2013).

\section{Závěr}

V haldovém materiálu na Rozvodném vrchu u Čabové bylo rozlišeno šest typů rud: jaspilitové rudy (s obsahy Fe pod 20 hm. \%), magnetit-hematitové jaspilitové rudy, křemen-hematitové rudy, křemen-magnetitové rudy, karbonátové rudy a chloritové rudy (v pěti posledních typech jsou průměrné obsahy Fe mezi 30 a 35 hm. \%). Na složení rud se podílí $\mathrm{v}$ různých proporcích hlavně křemen, magnetit, hematit, kalcit, siderit, chamosit a stilpnomelan; $\mathrm{k}$ běžným akcesoriím chloritových rud patří ilmenit, minerál skupiny $\mathrm{TiO}_{2}$, monazit-(Ce) a apatit. Protolitem chloritových rud je nejspíše produkt hydrotermální alterace bazických vulkanitů, příp. pyroklastik. Ostatní rudní typy se patrně vytvořily ze silicitů hydrotermálně sedimentárního původu s vysokým podílem oxidů a oxihydroxidů Fe s lokálními akumulacemi Fe-karbonátů a s príměsí pyroklastického materiálu.

\section{Poděkování}

Autoři děkují editorovi doc. RNDr. Zdeňku Lososovi, CSc. a recenzentovi prof. RNDr. Bohuslavu Fojtovi, CSc. za cenné rady a připomínky, které prispěly ke zkvalitnění tohoto článku.

\section{Literatura}

Burkart, E. (1953): Mährens Minerale und ihre Literatur. - Nakladatelství Československé akademie věd, Praha.

Cathelineau, M. (1988): Cation site occupancy in chlorites and illites as a function of temperature. - Clay Minerals, 23, 471-485. London.

Cathelineau, M. - Nieva, D. (1985): A chlorite solid solution geothermometer. The Los Azufres (Mexico) geothermal system. Contributions to Mineralogy and Petrology, 91, 235-244.

Dvořák, J. - Kalvoda, J. - Otava, J. - Přichystal, A. (1986): Zpráva o podrobném geologickém mapování v okolí Moravského Berouna. - Zprávy o geologických výzkumech v roce 1984, 59-60.

Geršl, M. - Knésl, I. (2009): Validace terénního rentgen-fluorescenčního spektrometru pro potřeby analýzy půd, říčních sedimentů a suspendované hmoty. - Geologické výzkumy na Moravě a ve Slezsku, XVI, 126-130.

Jowett, E.C. (1991): Fitting iron and magnesium into the hydrothermal chlorite geothermometer. - GAC/MAC/SEG Joint Annual Meeting (Toronto, May 27-29, 1991), Program with Abstracts 16, A62. Toronto.

Kopecká, L. (2012): Mineralogie železných rud typu Lahn-Dill ve šternbersko-hornobenešovském pruhu. - MS, diplomová práce. PřF UP Olomouc. $90 \mathrm{~s}$.

Kranidiotis, P. - MacLean, W.H. (1987): Systematics of chlorite alteration at the Phelps Dodge massive sulfide deposit, Matagami, Quebec. - Economic Geology, 82, 1898-1911.

Kretschmer, F. (1917): Die Erzführende Diabas- und Schalsteinzone Sternberg-Bennisch. - Archiv für Lagerstättenforschung, 24. Heft, 1-198.

Mátl, V. (1994): Jaspilit - málo známý netradiční drahý kámen. - Minerál, 2, 1, 42.

Mücke, A. - Dolníček, Z. - Fojt, B. - Hladíková, J. - Pudilová, M. - Reif, J. - Škoda, R. (2013): The Horní Benešov ore deposit in the Devonian Šternberk-Horní Benešov Belt, Jeseníky Mts, Czech Republic. Part II: Fe-ore occurrences. - Časopis Slezského zemského. muzea, Vědy př́rodní, 62, 3, 215-254.

Přichystal, A. (1986): Vulkanity šternbersko-hornobenešovského pruhu. - Zprávy o geologických výzkumech v roce 1984, 175-176.

Přichystal, A. (1990): Hlavní výsledky studia paleozoického vulkanismu ve šternbersko-hornobenešovském pruhu (Nízký Jeseník). - Sborník geologických věd, řada LGM, 29, 41-66.

Skácel, J. (1966): Železorudná ložiska moravskoslezského devonu. - Rozpravy Československé akademie věd, Řada matematických a př́rodních věd, 76, sešit 11, 3-59.

Skácel, J. (1968): Oblastní surovinová studie Jeseníky. - MS. Geologický průzkum, n. p. Ostrava.

Skácel, J. (2000): Přehled geologicko-průzkumných akcí na železné rudy v Jeseníkách a okolí po 2. světové válce. - Minerál, 8 , $4,309-312$.

Staněk, S. (1997): Tajemství podzemí. - In: Sborník „Hvězda pod Rosuticí“, 14-26, 146-147. Moravská expedice Moravský Beroun.

Šabatková, L. (2009): Mineralogie železných rud typu Lahn-Dill v okolí Moravského Berouna. - MS, diplomová práce. PřF UP Olomouc. $83 \mathrm{~s}$.

Tomšík, J. (1993): Vulkanosedimentární ložiska Fe rud na severní Moravě a ve Slezsku. - In: Přichystal, A. - Obstová, V. - Suk, M. (eds.): Geologie Moravy a Slezska, 71-78. Moravské muzeum Brno a PřF MU Brno.

Zang, W. - Fyfe, W.S. (1995): Chloritization of the hydrothermally altered bedrocks at the Igarapé Bahia gold deposit, Carajás, Brazil. - Mineralium Deposita, 30, 30-38.

Zimák, J. (1999): Stilpnomelan z akumulací Fe-rud lahn-dillského typu ve šternbersko-hornobenešovském pruhu a vrbenské skupině. - In: Seminář „Současné výzkumy v Sileziku“ u příležitosti životního jubilea prof. B. Fojta. Sborník abstraktů, 29-32. PřF MU Brno.

Zimák, J. (2015): Mineralogie železných rud z ložiska Řídeč v jižní části šternbersko-hornobenešovského pruhu (moravskoslezská jednotka Českého masivu). - Geologické výzkumy na Moravě a ve Slezsku, 22, 1-2, 25-28. 